ŁUKASZ FASZCZA

https://orcid.org/0000-0001-8667-3799

Uniwersytet Warszawski

\title{
STRATY W DRZEWOSTANIE LASÓW SKARBOWYCH NA ZIEMIACH POLSKICH POWSTAEE W WYNIKU DZIAŁAŃ WOJENNYCH ORAZ EKSPLOATACJI W OKRESIE I WOJNY ŚWIATOWEJ
}

Zarys treści: W artykule przedstawiono skalę zniszczeń w lasach skarbowych na obszarze Królestwa Polskiego oraz zachodnich guberni państwa rosyjskiego (wileńskiej, mińskiej, wołyńskiej, grodzieńskiej), które w okresie I wojny światowej znalazły się pod niemieckim zarządem okupacyjnym, a po jej zakończeniu stanowiły część odrodzonej Rzeczypospolitej. Spustoszenia w drzewostanach powstawały w wyniku bezpośrednich działań wojennych, dewastacji prowadzonych zarówno przez walczaccych żołnierzy, jak też ludność cywilna oraz eksploatacji gospodarczej. Na skalę zniszczeń wpływało wiele czynników, m.in. dostępność sieci transportowej (kolejowej, wodnej, drogowej), wielkość powierzchni leśnych, stopień zagospodarowania terenów zalesionych oraz przebieg linii frontu.

The content outline: The article discusses the scale of destruction in the Treasury forests located in the Kingdom of Poland and the western governorates of the Russian state (Vilna, Minsk, Volhynia, Grodno) which came under German occupation during World War I and formed part of the reborn Polish state after the end of the armed conflict. Damage inflicted on forest stands resulted from direct military operations, destruction brought by both soldiers and civilians, as well as economic exploitation. The scale of destruction was dictated by various factors, including the availability of transportation network (rail, waterways, roads), the size of forests, the level of development in forested areas and the location of the front lines.

Słowa kluczowe: lasy, straty, szacowanie, eksploatacja, I wojna światowa

Keywords: forests, losses, estimation, exploitation, World War I 


\section{Wstęp}

W 1936 r. ukazała się niezwykle barwna, popularnonaukowa praca zatytułowana Puszcze polskie. Jej autorem był znany ówcześnie literat i podróżnik Ferdynand Antoni Ossendowski. Wykorzystując w pełni swój artystyczny warsztat, stworzył on plastyczny oraz nasycony żywymi elementami obraz polskich lasów. Nie ograniczył się jednak do lirycznych opisów, umieszczając w tekście także wiele spostrzeżeń natury gospodarczej, odwołujacych się przede wszystkim do okresu I wojny światowej. Na łamach swojej książki wielokrotnie dawał wyraz oburzeniu z powodu zniszczeń dokonanych w polskich lasach, będących według niego głównie efektem niemieckiej eksploatacji ${ }^{1}$.

Zasadniczym celem niniejszego artykułu jest przedstawienie na podstawie dostępnego materiału źródłowego (głównie analiz szacunkowych wykonanych przez Departament Leśnictwa) skali zniszczeń powstałych w czasie I wojny światowej i próba znalezienia odpowiedzi na pytanie, czy rzeczywiście doszło w tym okresie do spustoszenia polskich lasów. Pozwoli to na przybliżoną ocenę potencjału gospodarki leśnej państwa polskiego w latach międzywojennych.

Używane w tekście określenie geograficzne „lasy na ziemiach polskich” oznacza tereny zalesione, które po zakończeniu I wojny światowej oraz okupacji $^{2}$ znalazły się w granicach II Rzeczypospolitej. W tym wypadku jednak analiza ogranicza się wyłącznie do obszarów będących podczas wojny pod zarządem niemieckim, tj. Generalnego Gubernatorstwa Warszawskiego (gubernie: warszawska, łomżyńska, płocka, kaliska i częściowo piotrkowska oraz siedlecka), Gebiet Oberbefehlshabers Ost, czyli Ober Ost (m.in. gubernie suwalska, grodzieńska i częściowo wileńska), Obszaru Etapowego Armii Woyschera (m.in. gubernie mińska oraz częściowo wileńska i siedlecka) i Obszaru Etapowego Armii Bugu (m.in. gubernie chełmska i wołyńska ${ }^{3}$. Takie zdefinowanie ram terytorialnych wynika z faktu, że stanowiace o sile przemysłu drzewnego oraz gospodarki leśnej II RP drzewostany w okresie Wielkiej Wojny znajdowały się właśnie w rękach niemieckich. Ponadto należy zaznaczyć, że badaniem objęte zostały wyłącznie lasy państwowe, biorąc w tym wypadku również

${ }^{1}$ F.A. Ossendowski, Puszcze polskie, Poznań 1936, s. 32, 74, 97, 160-163, 177, 184.

${ }^{2}$ Na obszarze m.in. Suwalszczyzny okupacja niemiecka trwała prawie do końca sierpnia 1919 r. W tym okresie także prowadzono eksploatację Puszczy Augustowskiej; por. T. Radziwonowicz, Suwalszczyzna w okresie I wojny światowej. Okupacja niemiecka 1915-1918, „Białostocczyzna” 38, 1995, nr 2, s. 18-24.

${ }^{3}$ H. Cronn, Geschichte des Deutschen Heeres im Weltkriege 1914-1918, Osnabrück 1990, s. 64, 67-68, 268-269, 271, 282-283. 
pod uwage dobra donacyjne (nadane rosyjskim oficerom lub urzędnikom) oraz majątki będące przed wojną w posiadaniu rodziny carskiej.

I wojna światowa zakończyła się ponad sto lat temu. Badanie zagadnień z nią związanych stanowi - wydawać by się mogło - wyłącznie odkrywanie kolejnych kart z minionych już wydarzeń. Twierdzenie to jednak nie do końca ma zastosowanie w przypadku prac poświęconych tematom z pogranicza nauk przyrodniczych, ponieważ skutki ingerencji człowieka w naturę widoczne sa niekiedy jeszcze po wielu latach. Obecny stan lasów w Polsce do pewnego stopnia wynika z wydarzeń z okresu 1914-1919. Niszczycielskie działania zbrojne, pożary i w końcu eksploatacja gospodarcza prowadzić mogły niekiedy do daleko idących zmian $\mathrm{w}$ drzewostanach oraz środowisku naturalnym. Analiza tych procesów pozwala z kolei ocenić stopień antropopresji, jakiej poddany został dany obszar, co zasadniczo wpływa na realizację działań zwiazanych $\mathrm{z}$ ochrona przyrody. Doskonałym przykładem w tym wypadku może być m.in. Puszcza Białowieska ${ }^{4}$.

\section{Baza źródłowa}

Po zakończeniu I wojny światowej i powstaniu niepodległego państwa polskiego lasy skarbowe znalazły się pod nadzorem Departamentu Leśnictwa w Ministerstwie Rolnictwa i Dóbr Państwowych (MRiDP). Priorytetem zarządzającej lasami państwowymi jednostki rządowej, począwszy od 1919 r., stało się określenie stopnia zalesienia kraju. Prace Departamentu Leśnictwa mające na celu szacunkowe wskazanie potencjału leśnego II RP zakończyły się ok. 1921 r. Sześć lat później zebrany materiał statystyczny został częściowo wydany w postaci oficjalnego zestawienia (publikacja uwzględniała dodatkowe analizy wykonane ok. 1923 r.), przedstawiajacego wielkość zasobów leśnych w Polsce z podziałem na poszczególne nadleśnictwa ${ }^{5}$. Sporządzony

${ }^{4}$ M. Latałowa, M. Zimny, B. Jędrzejewska, T. Samojlik, Ecological History of Biatowieża Forest - Europe's Last Primeval Woodland, w: The Ecological History of European Woodland an Interaction of Environmental and Cultural Forces, red. K. Kirby, C. Watkins, Oxford 2015, s. 243-264; R. Kowalczyk, Puszcza Białowieska. Ostatnia wyspa pierwotnej przyrody, https://puszcza.pracownia.org.pl/upload/filemanager/ puszcza/Puszcza\%20pliki/Puszcza-Bialowieska-Ostatnia-wyspa-Kowalczyk-2017.pdf (28 X 2017).

5 Sprawozdanie z działalności administracji lasów państwowych i władz ochrony lasów za okres 1919-1923, Warszawa 1927. Publikacja przedstawia stan ilościowy lasów państwowych na rok 1923. Począwszy od 1919 r. do lasów skarbowych włączano dobra rodziny carskiej, majoraty, donacje oraz prywatne majątki opuszczone przez właścicieli (wszystkie kategorie traktowano jako lasy państwowe); por. J. Broda, 
przez Departament Leśnictwa wykaz oceniony został przez środowisko naukowe jako stosunkowo poprawny, lecz daleki od dokładności. Zastrzeżenia budziły zwłaszcza szacunki dotyczące obszarów wschodnich II RP. Badacze zajmujący się poruszona problematyka, tj. Jan Miklaszewski, Włodzimierz Barański oraz Józef Broda ${ }^{6}$, wskazywali, że z dużą dozą prawdopodobieństwa dane zostały zaniżone, co wynikać mogło m.in. z błędnych obliczeń przeprowadzonych przez nieposiadający często wystarczających kwalifikacji personel leśny. Jednak mimo dostępnego już w 1923 r. opracowania poświęconego kondycji lasów na terenie państwa polskiego, sporządzonego przez Główny Urząd Statystyczny, analizy Departamentu Leśnictwa uważano wciąż za najbardziej miarodajne ${ }^{7}$.

Prace statystyczne Departamentu Leśnictwa ograniczone były niekiedy przez wydarzenia natury polityczno-militarnej. Sytuacja taka miała miejsce we wschodnich regionach państwa polskiego, tj. w województwach: wileńskim, poleskim, nowogródzkim i wołyńskim. Szacunki strat w drzewostanach tych obszarów przeprowadził Zarząd Dóbr Państwowych i Lasów, działajacy przy sprawującym kontrolę administracyjna na tym terenie Zarządzie Cywilnym Ziem Wschodnich $^{8}$. Opracowane przez wspomniana instytucję w 1919 r. analizy stanu gospodarczego lasów przekazane zostały Głównemu Urzędowi Likwidacyjnemu ${ }^{9}$, lecz z całą pewnością materiał ten trafił także do

Dzieje najnowsze leśnictwa w Polsce 1918-2006, t. 1, Warszawa 2007, s. 43; K. Bielański, O las polski, „Las Polski” 1921, nr 1, s. 20; Lasy polskie w świetle cyfr, „Las Polski” 1922, nr 9, s. 345-348.

${ }^{6}$ W. Barański, Kwestia drzewna w Polsce, Warszawa 1928, s. 12-15; J. Miklaszewski, Lasy i leśnictwo w Polsce, t. 1, Warszawa 1928, s. 18-21; J. Broda, dz. cyt., t. 1, s. $42-43$.

7 J. Kostyrko, Nieco nowych liczb z dziedziny statystyki lasów polskich, „Las Polski” 1924, nr 10, s. 412-414; J. Miklaszewski, dz. cyt., s. 56; L. Pączewski, Lasy. Przemyst $i$ handel drzewny $w$ Polsce, Warszawa 1924, s. 29-33, 53.

8 Zarząd Cywilny Ziem Wschodnich obejmował oprócz terytorium Litwy Środkowej także obszary m.in. Wołynia, Polesia, Grodzieńszczyzny. Departament Leśnictwa nie prowadził jednak szacunków nad stanem zniszczeń w lasach państwowych tylko na Wileńszczý́nie; por. W. Kozyra, Polityka administracyjna wtadz polskich na Ziemiach Wschodnich Rzeczypospolitej Polskiej w latach 1918-1926, „Annales Universitatis Mariae Curie Skłodowska. Sectio F”' 2005, nr 59, s. 422; J. Gierowska-Kałłaur, Zarzqd Cywilny Ziem Wschodnich, Warszawa 2003, s. 68-74; L. Pączewski, dz. cyt., s. 36-37.

${ }^{9}$ Główny Urząd Likwidacyjny został utworzony 31 I 1919 r., zajmował się ustalaniem strat wojennych oraz rewindykacją majątku zagrabionego przez okupantów niemieckich i austriackich na obszarze znajdującym się w granicach II RP. W tym celu wykorzystywał materiały zebrane m.in. przez MRiDP; por. Dekret o utworzeniu Głównego Urzędu Likwidacyjnego, „Dziennik Praw” 1919, nr 12, poz. 132. 
Departamentu Leśnictwa ${ }^{10}$. Ocena rzetelności danych z pewnością nie należy do prostych, jednak pojawiające się pojedyncze opinie, m.in. Miklaszewskiego czy Barańskiego, raczej negatywnie odnoszą się do rezultatów prac na leśna statystyką na obszarach wschodnich II RP ${ }^{11}$. Opracowanie materiału statystycznego utworzonym w tym celu komisjom nierzadko utrudniały napięte stosunki narodowościowe, a także agitacja bolszewicka. Wpływało to nie tylko na dokładność obliczeń, ale powodowało również, że wykazy z tego regionu mają więcej braków niż z obszaru GGW. Dodatkowy problem stanowi terytorium Litwy Środkowej, ponieważ nie ma pewności, jaka instytucja prowadziła tam prace ${ }^{12}$.

Niestety oryginalna dokumentacja opracowana przez Departament Leśnictwa nie zachowała się. Zebrane dane dostępne sa jednak w sporządzonych ok. 1922 r. ankietach GUL ${ }^{13}$, poświęconych zniszczeniom w lasach państwowych w okresie I wojny światowej. Każdy dokument ma pieczęć Ministerstwa Rolnictwa i Dóbr Państwowych, wobec czego nie ma raczej wattpliwości, że informacje statystyczne pochodzą właśnie z Departamentu Leśnictwa.

Innym źródłem informacji, o którym należałoby także wspomnieć, sa materiały szacunkowe opracowane bezpośrednio przez GUL ok. 1919 r. Dane te z cała pewnościa powstały zanim dobiegły końca prace prowadzone przez Departament Leśnictwa. Przy tworzeniu opracowania statystycznego GUL wykorzystywał niemieckie dokumenty z okresu okupacji, ale $\mathrm{w}$ dużej mierze kierował się jednak schematycznymi wyliczeniami (m.in. brano pod uwagę średnią ilość surowca drzewnego możliwą do pozyskania z 1 ha lasu). Analizy te z pewnościa stanowiły mniej wiarygodny materiał niż sporządzony przez Departament Leśnictwa, z czego urzędnicy GUL zdawali sobie sprawę, danych tych bowiem nie publikowano w żadnych oficjalnych raportach ${ }^{14}$.

${ }^{10}$ AAN, Główny Urząd Likwidacyjny (dalej: GUL), sygn. 762, List Prezydium Centralnego Towarzystwa Rolniczego do GUL, 1 VIII 1919 r., k. 18; tamże, List Centralnego Towarzystwa Rolniczego Naczelnego do Dowództwa Wojsk Polskich Zarząd Cywilny Ziem Wschodnich, 1 VIII 1919 r., k. 21-31; L. Pączewski, dz. cyt., s. 36-37, 198; M. Gołądek, Ustrój administracji ogólnej na Wileńszczyźnie w okresie międzywojennym, Gdańsk 2012, s. 8, 58-59.

${ }_{11}$ W. Barański, dz. cyt., s. 12-15; J. Miklaszewski, dz. cyt., s. 18-21.

${ }^{12}$ Litewskie Centralne Archiwum Państwowe, f. 13, sygn. 414, Sprawozdanie z inspekcji rejonów powiatu wileńskiego przeprowadzonej przez starostę powiatowego i zastępcę starosty w czasie od 18 do 31 marca, 1919 r., k. 35-36; AAN, Komisja Rewindykacyjna, sygn. 225, Załączniki Komisji Rewindykacyjnej w Warszawie, 90 arkuszy, b.p.

13 AAN, Komisja Rewindykacyjna, sygn. 225; tamże, sygn. 1128, List MRiDP do Komisji Rewindykacyjnej przy GUL, marzec 1922 r., b.p.

${ }^{14}$ AAN, GUL, sygn. 327, Straty wyrządzone w lasach podczas wojny, k. 61-65. 
Wartym uwzględnienia źródłem poświęconym omawianej problematyce jest również opracowanie pt. Rabunek niemiecki lasów polskich podczas wojny ${ }^{15}$, autorstwa bliżej nieznanego leśnika nazwiskiem Łuczycki. Tekst ten zawiera dużo cennych informacji na temat funkcjonowania okupacyjnej administracji leśnej (wyłącznie jednak na obszarze GGW), lecz budzi on także pewne zastrzeżenia. Wynikają one głównie ze stosunkowo mało obiektywnego i bardzo negatywnego stanowiska autora wobec władz okupacyjnych. Z kolei przytoczone przez Łuczyckiego analizy statystyczne na temat eksploatacji lasów stanowią wykluczające się nawzajem zestawienie dokumentów niemieckich oraz danych zaczerpniętych $\mathrm{z}$ literatury przedmiotu ${ }^{16}$. Autor opracowania niestety tylko lakonicznie wspominał o źródłach wykorzystywanych przy opracowywaniu swojego raportu. Były to bliżej nieznane (tylko w jednym wypadku dokładnie zacytował tytuł dokumentu), dziś już nieistniejące sprawozdania z tzw. niemieckiego archiwum leśnego ${ }^{17}$.

Oprócz wskazanego powyżej materiału źródłowego w niniejszym artykule pojawiają się również odniesienia do niemieckich dokumentów (bądź ich kopii) z okresu wojny, m.in. do raportów gospodarczych, dzienników urzędowych czy też różnego rodzaju rozporządzeń. Materiał ten, będący efektem pracy okupacyjnej administracji, nie budzi zastrzeżeń krytyki wewnętrznej, ponieważ stanowi przekaz mówiący o oficjalnych działaniach, z których dodatkowo zdawano relację organom decyzyjnym władz niemieckich (centralnym lub lokalnym). Uwagi dotyczą jedynie stanowiących część tego zbioru analiz szacunkowych, ponieważ dane tam zawarte nie muszą przedstawiać wszystkich strat, ale jedynie udokumentowany ich fragment.

${ }^{15}$ AAN, Komisja Rewindykacyjna, sygn. 1216, Łuczycki, Rabunek niemiecki lasów polskich podczas wojny, k. 1-34.

16 Tamże, k. 2-11.

17 Opuszczając w listopadzie 1918 r. Warszawę, Niemcy nie byli prawdopodobnie w stanie wywieść lub zniszczyć wszystkich dokumentów wytworzonych przez okupacyjna administrację GGW. Dotyczyło to m.in. materiałów poświęconych kwestiom gospodarczym, w tym także eksploatacji lasów. Dotyczące tej tematyki źródła skatalogowane $\mathrm{w}$ tzw. niemieckim archiwum leśnym trafiły po wojnie do magazynów MRiDP. Niestety do dziś ze zbioru liczącego pierwotnie 419 pozycji pozostały zaledwie szczątki w postaci trzech teczek przechowywanych w AGAD. Część dokumentów z katalogu archiwum leśnego przetrwała jednak w postaci kopii bądź też opracowanych na ich podstawie analiz, wykorzystywanych następnie przez administrację II RP; por. AAN, GUL, sygn. 349, Wykaz teczek akt niemieckich, traktujących o przedmiotach gospodarczych według podziału przyjętego w załączonym schemacie „Sprawozdanie dla komisji odszkodowań w Paryżu”, 1919 r., k. 327; AAN, GUL, sygn. 221; AGAD, Szef Administracji przy Generał-Gubernatorstwie Warszawskim, sygn. $49,50,51$. 
Uzupełnieniem bazy źródłowej są materiały powstałe w zwiąku z działalnością administracji leśnej II RP. Dokumenty wielu nadleśnictw, poświęcone głównie pracom nad planami urządzania lasu, przedstawiaja stan gospodarczy będący w dużej mierze wynikiem zniszczeń oraz wojennej eksploatacji.

\section{Stan badań}

Pierwsza analizę strat w drzewostanie lasów na ziemiach polskich będacych w okresie I wojny światowej pod niemiecką okupacja, mająca wiarygodne odniesienia źródłowe ${ }^{18}$, sporządził pracownik Ministerstwa Robót Publicznych, absolwent Politechniki Warszawskiej oraz Drezdeńskiej, Adam Czerniaków ${ }^{19}$. Opracowanie to ukazało się jednak dopiero w 1921 r. Nietrudno się domyśleć, że wiązało się to z zakończeniem prac statystycznych nad stanem lasów państwa polskiego prowadzonych przez Departament Leśnictwa. Mimo to Czerniaków w opracowanym artykule odwoływał się do danych GUL. Przeprowadzone przez niego wyliczenia wykazały, jakoby straty w drzewostanie lasów państwowych, powstałe w wyniku działań zbrojnych, grabieży oraz eksploatacji, sięgnęły wielkości $32,5 \mathrm{mln} \mathrm{m}^{3}$, co dawać miało wielkość równą 30 rocznym etatom cięć. Poza tym Czerniaków szacował także, że Niemcy pozostawili po sobie ok. 355 tys. ha zrębów. Niestety nie określił, do jak dużego obszaru niemieckiej okupacji odnoszą się te dane. Bez watpienia jednak to opracowanie nie przedstawia całościowej skali zniszczeń powstałych w polskich lasach w okresie I wojny światowej ${ }^{20}$.

18 Artykuł Czerniakowa poprzedziły trzy teksty także zawierające analizy strat w drzewostanie lasów na ziemiach polskich w okresie I wojny światowej. Ich autorami byli Jan Miklaszewski, hrabia Zygmunt Plater oraz Stefan Kader. Niestety żaden z nich nie wskazał precyzyjnie wykorzystywanej w swojej pracy bazy źródłowej. Uniemożliwia to w praktyce ocenę tych analiz; por. J. Miklaszewski, Lasy na ziemiach polskich $i$ ich los podczas inwazji, „Sylwan” 1917, nr 10-12, s. 233-253; Z. Plater, Lasy polskie przed, podczas i po wojnie, Kraków 1918; S. Kader, Katastrofalna gospodarka. Sprawa leśna i opałowa na Litwie i Rusi, Wilno 1920.

19 Encyklopedia Warszawy, red. S. Herbst, Warszawa 1994, s. 123; M. Urynowicz, Adam Czerniaków 1880-1942: prezes getta warszawskiego, Warszawa 2009, s. 68-72.

${ }^{20}$ A. Czerniaków, Lasy $i$ ich zniszczenie $w$ bytym Królestwie Polskim i Małopolsce, „Roboty Publiczne” 1921, nr 1, s. 21-22. Artykuł w praktycznie niezmienionej postaci znalazł się w opracowaniu książkowym Leona Pączewskiego (tenże, dz. cyt.). Podane w nim dane statystyczne wykorzystał także Hipolit Gliwic; zob. tenże, Przemyst $i$ handel Polski, w: Polska $w$ czasie wielkiej wojny (1914-1918). Historia spoteczna i ekonomiczna, t. 3: Historia ekonomiczna, red. M. Handelsman, H. Gliwic, W. Grabski, K. Konarski, K.W. Kumaniecki, S. Kutrzeba, J. Stachiewicz, Warszawa 1936, s. 312-317. 
W latach trzydziestych XX w. na podstawie materiałów statystycznych wytworzonych przez władze GGW powstały dwie rozprawy poświęcone analizie zniszczeń w lasach w okresie I wojny światowej, dotyczace jednak wyłącznie centralnego obszaru okupowanego przez Niemców Królestwa Polskiego. Autorami tekstów byli Halina Jabłońska oraz zespół naukowców: Władysław Grabski, Jan Warężak i Józef Stojanowski. Opracowane przez wymienionych badaczy dane na temat strat w drzewostanie różniły się jednak dość znacząco. Szacunki Jabłońskiej wskazywały, że władze niemieckie pozyskały z lasów na obszarze GGW $5710791 \mathrm{~m}^{3}$ drewna, a wyliczenia opublikowane w obszernym artykule zawartym w tomie trzecim pracy Polska $w$ czasie wielkiej wojny (1914-1918). Historia społeczna i ekonomiczna pt. Historia ekonomiczna, której autorami byli wspomniani naukowcy, sugerowały wielkość ok. 9,5 mln $\mathrm{m}^{3}$. Podkreślić należy, że w obu przypadkach analiza dotyczyła sumy strat z lasów skarbowych oraz prywatnych. Tak duże rozbieżności wynikały zapewne z doboru bazy źródłowej. Jabłońska w swoim tekście odwoływała się bowiem wyłącznie do raportów gospodarczych władz GGW, natomiast trójka pozostałych badaczy, tj. Grabski, Warężak i Stojanowski, korzystała ze znacznie większej liczby niemieckich dokumentów. Poza cytowanymi artykułami informacje na temat eksploatacji lasów z obszaru GGW odnaleźć można w wydanym w 1934 r. tekście szefa okupacyjnej Administracji Cywilnej GGW Wolfganga von Kriesa. Korzystając zapewne głównie z kopii raportów gospodarczych, określił on wielkość pozyskanego przez Niemców surowca na $6,65 \mathrm{mln} \mathrm{m}^{3}$. Wyliczenia powstałe na podstawie materiałów źródłowych wytworzonych przez okupacyjna administrację mają jednak zasadnicza wadę. Jak już wspomniano, nie przedstawiaja one bowiem całkowitych strat w drzewostanie, a jedynie pewną część udokumentowanej eksploatacji gospodarczej $^{21}$.

Po II wojnie światowej temat strat w leśnictwie spowodowanych poprzednim dziejowym konfliktem nie budził raczej zainteresowania. Najbardziej wartościowym opracowaniem z tego okresu jest artykuł Jana Miklaszewskiego, który ukazał się na łamach „Sylwana” w 1947 r. Autor odwołując się do materiałów źródłowych opracowanych przez Departament Leśnictwa na początku lat dwudziestych, stwierdził, że lasy na ziemiach polskich, biorac jednak w tym wypadku pod uwage

${ }^{21}$ H. Jabłońska, Lasy b. Królestwa Polskiego pod okupacja niemiecka, Warszawa 1939, s. 31-34; W. von Kries, Die wirtschaftliche ausnutzung des Generalgouvernements Warschau, „Preußische Jahrbücher” 1934, nr 235, s. 234; W. Grabski, J. Warężak, J. Stojanowski, Rolnictwo Polski 1914-1920, w: Polska w czasie wielkiej wojny..., s. 314 . 
również galicyjskie drzewostany, poniosły w czasie I wojny światowej starty przekraczające $50 \mathrm{mln} \mathrm{m}^{3}$ surowca. Z niezrozumiałych względów praca Miklaszewskiego, cytowana wprawdzie jeszcze w monumentalnym dziele pt. Dzieje lasów, leśnictwa $i$ drzewnictwa $w$ Polsce wydanym w $1965 \mathrm{r}^{22}$, dzisiaj jest praktycznie zapomniana ${ }^{23}$. Informacje na temat zniszczeń w lasach spowodowanych dziejowym konfliktem pojawiają się dość często w tekstach poświęconych historii regionalnej, lecz ich autorzy albo nie podają źródeł, albo też cytują wcześniej wymienionych badaczy ${ }^{24}$.

W'śód badań dotyczacych strat w drzewostanach poniesionych w okresie wojny przez konkretne drzewostany najwięcej informacji znaleźć można na temat Puszczy Białowieskiej. Prace poświęcone temu zagadnieniu prowadzone były m.in. przez wybitnego polskiego botanika Władysława Szafera ${ }^{25}$. W jednym z tekstów podał on informację, że w okresie wojny białowieskie lasy (liczone jako jeden drzewostan wraz z Puszczą Świsłocka) straciły ok. 1,8 $\mathrm{mln} \mathrm{m}^{3}$ surowca drzewnego ${ }^{26}$. Źródłem tych danych był artykuł inżyniera Mariana Nawrockiego, który oceniając w 1919 r. na łamach periodyku „Roboty Publiczne” stan Puszczy Białowieskiej, stwierdził (powołując się na informację udzieloną mu w komisariacie w miejscowości Prużany), że w czasie wojny Niemcy wycięli nie więcej niż $1,8 \mathrm{mln} \mathrm{m}^{3}$ drzewa $^{27}$. Z kolei $\mathrm{w}$ innym tekście, pisanym z pewnością w późniejszym czasie, Szafer, odwołując się prawdopodobnie do szacunków opracowanych przez Departament Leśnictwa, podał już inną wysokość strat białowieskich drzewostanów, sięgająca

${ }^{22}$ R. Fromer, Okres pierwszej wojny światowej, w: Dzieje lasów, leśnictwa i drzewnictwa $w$ Polsce, red. J. Broda, A. Żabko-Potapowicz, Warszawa 1965, s. 306.

${ }^{23}$ J. Miklaszewski, Rzut oka na dzieje $i$ stan leśnictwa $i$ towiectwa polskiego w okresie 1918-1939, „Sylwan” 1947, nr 1/4, s. 12-13.

${ }^{24}$ J. Karpiński, Białowieża, Warszawa 1947, s. 31; P. Bajko, Białowieża. Zarys dziejów do 1950 roku, Białowieża 2001, s. 61-64; W. Ripperger, W. Semakow, Der Traum von Urwald, Tessin 2008, s. 182-185; W. Semakow, Bialowieskaja Puszcza, Mińsk 2002, s. 36-41; H. Stasiewicz, Knyszyn i ziemia knyszyńska, Knyszyn 1997, s. 116-117; Z. Lorenc, I wojna światowa w gminie Jednorożec, Jednorożec 2003, s. 74; A. Laszuk, Puszcza Knyszyńska w latach 1914-1939, „Podlasie” 1988, nr 1, s. 31-32; E. Więcko, Dzieje Puszczy Białowieskiej od rozbiorów do roku 1918, KHKM, t. 11, 1963, nr 2, s. 343; W. Batura, Dzieje Puszczy Augustowskiej, „Jaćwież” 2001, nr 13, s. 17; E. Więcko, Lasy i przemyst drzewny w Polsce, Warszawa 1960, s. 97-98.

${ }^{25}$ P. Köhler, Szafer Wtadystaw Józef, krypt. W.S. (1886-1970), w: PSB, t. 46, Warszawa 2009, s. 401-407.

${ }^{26}$ W. Szafer, Plan utworzenia rezerwatu leśnego w Puszczy białowieskiej, Lwów 1920, s. 16.

${ }^{27}$ M. Nawrocki, Puszcza Białowieska, „Roboty Publiczne” 1919, nr 5, s. 32. 
ok. $1,5 \mathrm{mln} \mathrm{m}^{3}$ surowca drzewnego ${ }^{28}$. Podobnie w tym temacie wypowiedział się badacz zagadnień gospodarczych dr Leon Pączewski, który czerpiąc z danych Departamentu Leśnictwa (co wskazał w pracy), także określił poziom strat w Puszczy Białowieskiej w granicach ok. 1,5 mln $\mathrm{m}^{3}$ drzewa. W publikacji wspomnianego autora znalazły się dodatkowo informacje na temat drzewostanów Litwy Środkowej. Niestety zbiorcze zestawienie odnosiło się zarówno do lasów prywatnych, jak i skarbowych z tego regionu. Poza tym analiza ta, poświęcona zniszczeniom w lasach Wileńszczyzny, dotyczyła nie tylko pierwszowojennego konfliktu, ale również wojny polsko-bolszewickiej, co utrudnia wykorzystanie tych danych w niniejszym tekście ${ }^{29}$.

\section{Zniszczenia wojenne oraz eksploatacja lasów na ziemiach polskich w czasie I wojny światowej. Próba ilościowego ujęcia}

Opracowania Departamentu Leśnictwa z lat 1919-1921 poświęcone zniszczeniom $\mathrm{w}$ lasach państwowych zostały wykonane $\mathrm{z}$ uwzględnieniem podziału administracyjnego drzewostanów skarbowych na nadleśnictwa ${ }^{30}$. Wykorzystana w pracach szacunkowych struktura organizacji lasów nie odzwierciedlała jednak stanu z okresu II RP ${ }^{31}$. Zilustrowany w materiałach Departamentu Leśnictwa schemat odnosił się jeszcze do okresu okupacji, lecz z dużą dozą pewności można stwierdzić, że władze niemieckie w większości zachowały kształt granic nadleśnictw jeszcze sprzed sierpnia $1914 \mathrm{r}$. Według danych opracowanych przez agendę MRiDP obszar lasów skarbowych - podzielony na 55 dystryktów $^{32}$

${ }^{28}$ W. Szafer, Z Puszczy Białowieskiej. Wrażenia z wycieczek do Puszczy odbytych w 1919 i 1920 r., „Orli Lot” 1920, nr 8, s. 101.

${ }^{29}$ L. Pączewski, dz. cyt., s. 36-37.

30 Zebrany materiał dokumentacyjny jest wykazem stosunkowo kompletnym. Tylko w ośmiu przypadkach (nadleśnictwa: Jezioro, Prypeć, Łuniniec, Zabłocie Czartorysk, Snowiedowice, Sarny, Wilejka) arkusze zawierają niepełne dane. Poza tym w kilku dokumentach szacunki zostały ewidentnie zaokraglone (np. w nadleśnictwie Wołkowysk). Problematycznie przedstawione zostały także dane na temat żywicowania, ponieważ w rubrykach dotyczących tego zagadnienia pojawia się niekiedy cyfra zero, a w innych przypadkach rubryka jest pusta. Trudno orzec, czy oba oznaczenia odnoszą się do tej samej sytuacji; zob. aneks.

${ }^{31}$ Podlaska Biblioteka Cyfrowa, Mapa Przeglądowa Lasów Państwowych Rzeczypospolitej Polskiej z 1933 r.

${ }^{32}$ Wykorzystany przez MRiDP schemat podziału lasów skarbowych przedstawia prawdopodobnie plan jeszcze sprzed wybuchu wojny. Niemieckie władze okupacyjne administrowały bowiem według zupełnie innej struktury terytorialnej; por. AAN, 
składających się z 90 nadleśnictw, zajęty przez niemiecki zarząd okupacyjny - wyniósł 1297864 ha. Działania wojenne, grabieże, dewastacje, pożary oraz eksploatacja doprowadziły do powstania łącznie 77157 ha zrębów ${ }^{33}$. Do tego dodać należy również straty spowodowane niewłaściwym żywicowaniem borów sosnowych na powierzchni 13142 ha, w których drewno straciło wartości użytkowe (mogło służyć jedynie jako opal $)^{34}$. Ilość surowca wyciętego lub zniszczonego w lasach państwowych na badanym obszarze w okresie od 1914 do lata 1919 r., według analizy Departamentu Leśnictwa, wyniosła $25560889 \mathrm{~m}^{3}$ drewna użytkowego oraz $10104072 \mathrm{~m}^{3}$ drewna opałowego. Razem dawało to $35664961 \mathrm{~m}^{3}$ surowca ${ }^{35}$.

Opracowane dane statystyczne nie przedstawiaja jednak całości strat, jakie poniosły lasy na ziemiach polskich w okresie I wojny światowej. Analizy Departamentu Leśnictwa nie uwzględniały m.in. terytorium Litwy Środkowej. Materiał badawczy z tego regionu (nie wiadomo przez kogo opracowany) różnił się od obliczeń sporządzonych w innych częściach ziem polskich, nie odnotowując m.in. areału poddanego żywicowaniu czy wielkości nadleśnictw. Zdecydowanie większym problemem staje się jednak fragmentaryczność posiadanych analiz. W czasie kwerendy $\mathrm{w}$ polskich i litewskich archiwach udało się odnaleźć statystyki poświęcone zaledwie pięciu leśnictwom ${ }^{36}$ (wszystkie w AAN). Dane tam

Komisja Rewindykacyjna, sygn. 1216, Łuczycki, Rabunek niemiecki lasów polskich podczas wojny, k. 2, 8-9; AGAD, Szef Administracji przy Generał-Gubernatorstwie Warszawskim, sygn. 5, Vierteljahresbericht des Verwaltungschefs bei dem General-Gouvernement Warschau für die Zeit vom 1. Januar 1916 bis zum 31. März 1916, k. 28-34.

${ }^{33}$ Materiał źródłowy nie precyzuje, czy były to zręby częściowe, czy też zupełne.

${ }^{34}$ Według dostępnych źródeł oraz literatury Niemcy żywicowali w czasie wojny wyłącznie sosnę, nie prowadząc podobnych prób na świerkach. Osobom pracującym nad pozyskiwaniem żywicy często brakowało odpowiednich umiejętności oraz narzędzi, co prowadziło do zniszczeń w drzewostanie; por. AAN, Komisja Rewindykacyjna, sygn. 1216, Łuczycki, Rabunek niemiecki lasów polskich podczas wojny, k. 17-18; J. Fijałkowski, Żywicowanie sosny pospolitej w lasach państwowych, „Las Polski” 1922, nr 7-8, s. 273.

${ }_{35}$ Porównując wielkość powierzchni zrębów (77 157 ha) z ilością wyciętego surowca (35 $664961 \mathrm{~m}^{3}$ ), można obliczyć średni wskaźnik wysokości wyrębów, który wynosić miałby w tym wypadku $462 \mathrm{~m}^{3}$ drewna z hektara. Według ówczesnych szacunków (lata dwudzieste XX w.) z hektara powierzchni leśnej uzyskiwało się ok. $250 \mathrm{~m}^{3}$ surowca. Tak duża rozbieżność danych wskazywać może, że sporządzone przez Departament Leśnictwa analizy były zaniżone; por. W. Jedliński, Kilka uwag $w$ sprawie stanu posiadania $i$ samowystarczalności $w$ zakresie produkcji drewna, „Las Polski” 1929, nr 1, s. 10-11; L. Pączewski, dz. cyt., s. 36-37.

${ }^{36}$ Materiał statystyczny dotyczy leśnictw: intruskiego, międzyrzeckiego, rudnickiego, szyrwińskiego i trockiego. W okresie funkcjonowania Zarządu Cywilnego Ziem 
zawarte pozwoliły oszacować, że całkowity obszar zrębów na badanym obszarze wyniósł ok. 2250 ha. $\mathrm{Z}$ areału tego władze niemieckie pozyskały ok. $975 \mathrm{~m}^{3}$ drewna użytkowego oraz ok. $372 \mathrm{~m}^{3}$ opałowego (razem $1347 \mathrm{~m}^{3}$ ). Liczby te budzą jednak pewne wątpliwości, ponieważ wykazany rozmiar eksploatacji jest stosunkowo niewielki. Opracowaniu dokładnych danych na temat strat w lasach Wileńszczyzny nie służą również szacunki sporządzone przez Pączewskiego. Podany przez niego rachunek zniszczeń w wysokości $1,3 \mathrm{mln}^{3}$ surowca odnosi się zarówno do kompleksów skarbowych, jak i prywatnych (razem dawało to 9800 ha), a do tego uwzględnia również szkody powstałe w czasie wojny polsko-bolszewickiej ${ }^{37}$. Pewne braki wykazuja ponadto materiały Departamentu Leśnictwa, których autorzy nie przekazali danych z nadleśnictw Wilejka-Duniłowicze, Sarny, Czartorysk oraz częściowo z nadleśnictwa Prypeć i Snowiedowice. Nieprzypadkowo zapewne wszystkie z wymienionych regionów znajdowały się na Kresach Wschodnich II RP ${ }^{38}$.

Sumujac dane zawarte $\mathrm{w}$ wykorzystanym materiale statystycznym, możemy stwierdzić, że z lasów na ziemiach polskich będących w czasie I wojny światowej pod okupacja niemiecka (ich areał wynosił ok. $1300000 \mathrm{ha}^{39}$ ) wycięto ponad $35,5 \mathrm{mln} \mathrm{m}^{3}$ surowca drzewnego.

Wschodnich na obszarze Litwy Środkowej funkcjonowały nadleśnictwa: rudnickie, wileńskie, intruskie, święciańskie; por. AAN, Komisja Rewindykacyjna, sygn. 225, Wykaz strat wynikłych z Zarządu Przymusowego, 1919 r., b.p.; tamże, Leśnictwo międzyrzeckie, nadleśnictwo rudnickie - wykaz rejestracyjny dochodów pobranych przez niemiecką władzę okupacyjna z leśnictwa międzyrzeckiego, b.p.; tamże, Leśnictwo intruskie, nadleśnictwo intruskie - wykaz rejestracyjny dochodów pobranych przez niemiecką władzę okupacyjną z leśnictwa intruskiego, b.p.; tamże, Leśnictwo szyrwińskie, nadleśnictwo intruskie - wykaz rejestracyjny dochodów pobranych przez niemiecką władzę okupacyjną z leśnictwa szyrwińskiego, b.p.; tamże, Leśnictwo trockie, nadleśnictwo wileńskie - wykaz rejestracyjny dochodów pobranych przez niemiecka władzę okupacyjną z leśnictwa wileńskiego, b.p.; Litewskie Centralne Archiwum Państwowe, f. 13, sygn. 414, Instrukcja dla urzędników lokalnych dóbr państwa okręgu wileńskiego, 9 VIII 1919 r., k. 30.

${ }_{37}$ L. Pączewski, dz. cyt., s. 37.

38 AAN, Komisja Rewindykacyjna, sygn. 225, Załączniki Komisji Rewindykacyjnej w Warszawie - Nadleśnictwa Wilejka-Duniłowicze, Sarny, Czartorysk, Prypeć, Snowiedowice, b.p.; W. Barański, dz. cyt., s. 12-15; J. Miklaszewski, Lasy i leśnictwo w Polsce..., s. 18-21.

${ }^{39} \mathrm{Z}$ danych Departamentu Leśnictwa wynika, że pod okupacją niemiecka znajdowało się 1297864 ha lasu. Do tego należy dodać kompleksy obszaru Litwy Środkowej. W województwie wileńskim II RP lasy skarbowe stanowiły $28 \%$ wszystkich terenów zalesionych. Wartość taka przyporządkowana została również Litwie Środkowej, której kompleksy leśne wynosiły ok. 9800 ha; por. AAN, Komisja Rewindykacyjna, sygn. 225, Załączniki Komisji Rewindykacyjnej w Warszawie, b.p.; L. Pączewski, dz. cyt., s. 37 . 
Gdybyśmy dodali do tego również wielkość eksploatacji drzewostanów na obszarze Litwy Środkowej oraz nieuwzględnionych w materiałach Departamentu Leśnictwa nadleśnictw to ogólna liczba strat w lasach ziem polskich $\mathrm{w}$ okresie wojny przekroczyłaby z pewnością wartość $40 \mathrm{mln} \mathrm{m}^{3}$ surowca (biorąc również pod uwagę głosy badaczy mówiące o zaniżonych wartościach $\mathrm{w}$ szacunkach drzewostanów na obszarze Kresów Wschodnich II RP) ${ }^{40}$.

Jaka wobec wskazanych powyżej szacunków była rzeczywista skala strat $\mathrm{w}$ lasach na badanym obszarze? Czy $40 \mathrm{mln}^{3}$ drewna to rzeczywiście dużo, czy może wręcz przeciwnie? Do zilustrowania wielkości strat w drzewostanie lasów na ziemiach polskich będących pod niemieckim zarządem w czasie I wojny światowej należałoby skonfrontować te dane z okresem późniejszym, tj. II Rzeczypospolitej. Areał lasów skarbowych państwa polskiego $\mathrm{w}$ dwudziestoleciu międzywojennym wynosił ok. 2486000 ha (obszar większy o ponad 1186000 ha od tego, którym dysponowały władze niemieckie). Roczny etat cięć szacowany był $\mathrm{w}$ nich na ok. $8 \mathrm{mln}^{3}$ drzewa. Zastosowanie równania pierwszego stopnia z jedną niewiadomą wskazuje, że roczny etat cięć na obszarze okupowanym przez władze niemieckie powinien wynosić ok. $3,8 \mathrm{mln}^{3}$ drzewa, czyli ok. $15 \mathrm{mln} \mathrm{m}^{3}$ surowca $\mathrm{w}$ ciagu czterech lat. Tymczasem z lasów na ziemiach polskich ubyło o ok. $25 \mathrm{mln} \mathrm{m}^{3}$ więcej drewna, co odpowiada sześciu dodatkowym etatom rocznym. Wobec tego nie ma raczej wątpliwości, że okres I wojny światowej miał decydujacy wpływ na zubożenie potencjału leśnego II RP. Przyczyniły się do tego zniszczenia wojenne, grabieże, dewastacja, ale przede wszystkim eksploatacyjna gospodarka prowadzona przez okupanta. Bardzo trudno wskazać jednak dokładne dane na temat strat wynikających z konkretnych działań, w szczególności spowodowanych dewastacja, pożarami czy ostrzałem artyleryjskim ${ }^{41}$.

${ }^{40}$ AAN, Komisja Rewindykacyjna, sygn. 225, Leśnictwo międzyrzeckie, nadleśnictwo rudnickie - wykaz rejestracyjny dochodów pobranych przez niemiecka władzę okupacyjną z leśnictwa międzyrzeckiego, b.p.; tamże, Leśnictwo intruskie, nadleśnictwo intruskie - wykaz rejestracyjny dochodów pobranych przez niemiecka władzę okupacyjną z leśnictwa intruskiego, b.p.; tamże, Leśnictwo szyrwińskie, nadleśnictwo intruskie - wykaz rejestracyjny dochodów pobranych przez niemiecka władzę okupacyjną z leśnictwa szyrwińskiego, b.p.; tamże, Leśnictwo trockie, nadleśnictwo wileńskie - wykaz rejestracyjny dochodów pobranych przez niemiecką władzę okupacyjną z leśnictwa wileńskiego, b.p.; tamże, Załączniki (90 protokołów) Komisji Rewindykacyjnej w Warszawie, b.p.; L. Pączewski, dz. cyt., s. 36-37; W. Barański, dz. cyt., s. 12-15; J. Miklaszewski, Lasy i leśnictwo w Polsce..., s. 18-21.

${ }^{41}$ Sprawozdanie z działalności administracji lasów państwowych..., s. 34; W. Jedliński, dz. cyt., s. 7-13; J. Broda, dz. cyt., t. 1, s. 147-156; W. Barański, dz. cyt., s. 26. 


\section{Uwarunkowania niemieckiej eksploatacji}

Dewastacja drzewostanów w lasach na ziemiach polskich była rezultatem wielu nakładających się na siebie przyczyn. Poniższe zestawienie przedstawia rozmiary strat $\mathrm{w}$ surowcu drzewnym $\mathrm{z}$ wybranych ziem polskich będących w czasie wojny pod niemieckim zarządem okupacyjnym.

Tabela 1. Straty w drzewostanie w wybranych nadleśnictwach na ziemiach polskich powstałe w okresie I wojny światowej

\begin{tabular}{|c|c|c|c|c|c|c|c|}
\hline Dystrykt & $\begin{array}{c}\text { Nadle- } \\
\text { śnictwo }\end{array}$ & $\begin{array}{c}\text { Obszar } \\
\text { nadle- } \\
\text { śnictwa } \\
\text { w ha }\end{array}$ & $\begin{array}{c}\text { Straty } \\
\text { w drew- } \\
\text { nie użyt- } \\
\text { kowym } \\
\text { w m }^{3}\end{array}$ & $\begin{array}{c}\text { Straty } \\
\text { w drew- } \\
\text { nie opa- } \\
\text { lowym } \\
\text { w m }^{3}\end{array}$ & $\begin{array}{c}\text { Straty } \\
\text { ogółem } \\
\mathbf{w ~ m}^{3}\end{array}$ & $\begin{array}{l}\text { Średnia } \\
\text { ilość } \\
\text { strat } \\
\mathbf{w ~ m} \mathbf{~ m}^{3} \\
\mathrm{z} \mathrm{ha}\end{array}$ & $\begin{array}{c}\text { Obszar } \\
\text { żywi- } \\
\text { cowany } \\
\text { w ha }\end{array}$ \\
\hline Lida & Lida & 18944 & 1950198 & 729816 & 2680014 & 141 & brak inf. \\
\hline Sokółka & $\begin{array}{l}\text { Czarna } \\
\text { Wieśs }\end{array}$ & 27500 & 1597931 & 529307 & 2127238 & 77 & 991 \\
\hline Grodno & Jezioro & 15739 & 379056 & 777787 & 1156843 & 73 & 515 \\
\hline Baranowicze & Kołpienie & 23869 & 837955 & 267455 & 1105410 & 46 & 161 \\
\hline Kowel & Kowel & 18000 & 770104 & 306140 & 1076244 & 59 & brak inf. \\
\hline Słonim & Dereczyn & 28972 & 917753 & 128564 & 1046317 & 36 & brak inf. \\
\hline Brześć & Brześć & 17982 & 713027 & 214290 & 927317 & 51 & brak inf. \\
\hline Gostynin & Gostynin & 8700 & 596950 & 218031 & 814981 & 93 & 120 \\
\hline Będzin & $\begin{array}{l}\text { Janów- } \\
\text {-Biała }\end{array}$ & 12000 & 550770 & 231355 & 782125 & 65 & brak inf. \\
\hline Augustów & $\begin{array}{l}\text { Szczebra- } \\
\text {-Olszanka }\end{array}$ & 16921 & 546049 & 227868 & 773917 & 45 & 220 \\
\hline Wołożyn & Bakszty & 54332 & 544879 & 209508 & 754387 & 13 & 10 \\
\hline Sejny & Krasnopol & 13534 & 587774 & 163458 & 751232 & 55 & 80 \\
\hline
\end{tabular}

Źródło: AAN, Komisja Rewindykacyjna, sygn. 311, Załączniki Komisji Rewindykacyjnej w Warszawie Nadleśnictwa Lida, Czarna Wieś, Jezioro, Kołpienie, Kowel, Dereczyn, Brześć, Gostynin, Janów-Biała, Szczebra-Olszanka, Bakszty, Krasnopol, b.p.

Prezentowane zestawienie odnosi się do wybranych dwunastu nadleśnictw, które w okresie I wojny światowej poniosły najwyższe straty $\mathrm{w}$ drzewostanie. Jednak ważne sa w nim nie tylko liczby obrazujące skalę zniszczeń, ale też wynikające z nich uwarunkowania.

Stopień dewastacji drzewostanu na danym obszarze wynikał w dużej mierze z przebiegu działań wojennych. Nie chodzi tu bynajmniej wyłącznie o same walki, ale również o przygotowania do dużych kampanii bądź też po prostu stacjonowanie wojsk. Obie sytuacje generowały ogromne potrzeby materiałowe, zarówno jeżeli idzie o drzewo budowlane, jak 
i opałowe. Potężna ofensywa niemieckiej 10. Armii gen. Hermana von Einchorna z sierpnia 1915 r., skierowana przeciwko twierdzy Kowno, przygotowywana była pod osłoną lasów zaniemeńskich. Podobnie działo się w przypadku dalszych działań w kierunku linii Niemna, na czele z oblężeniem twierdzy grodzieńskiej. Front wschodni jesienią 1915 r. zatrzymał się na linii Dyneburg - jezioro Narocz - Smorgonie, ciagnąc się dalej na wschód od Baranowicz, wzdłuż Kanału Ogińskiego w kierunku na Pińsk i Dubno. Znajdujące się na tym obszarze lasy stały się prawdopodobnie zapleczem materiałowym niemieckich wojsk praktycznie aż do 1918 r. Nadleśnictwa $z$ tego regionu poniosły największe straty ze wszystkich znajdujących się pod niemieckim zarządem okupacyjnym. Poza tym podkreślić należy, że żołnierze na obszarze przyfrontowym pobierali surowiec z lasów na własną rękę (na terenach oddalonych od linii frontu było to zabronione), przyczyniajac się w ten sposób do ogromnego spustoszenia w drzewostanie. Dewastacje lasów przez żołnierzy czyniły niekiedy większe szkody niż bezpośrednie działania wojenne ${ }^{42}$.

Analizując temat zniszczeń $\mathrm{w}$ drzewostanach spowodowanych działaniami wojennymi oraz samowolą żołnierzy, nie można zapomnieć, że problem ten dotyczył w równym stopniu wojska niemieckiego, jak i rosyjskiego. Nie podlega dyskusji, że żołnierze carscy również potrzebowali drewna, zarówno budulca, jak i opału. Z nielicznych zachowanych dokumentów z przełomu 1914 i 1915 r. dotyczących stacjonowania wojsk rosyjskich w okolicach Augustowa wynika, że dostarczaniem materiału drzewnego wojsku zajmowała się w tym czasie prawdopodobnie lokalna administracja leśna ${ }^{43}$. Praktyki carskich żołnierzy nie odbiegały zapewne od działań niemieckich. Przypuszczalnie rosyjska eksploatacja doprowadziła w dużej mierze do ogromnego spustoszenia drzewostanu w nadleśnictwie Czarna Wieś (Puszcza Knyszyńska). Poziom eksploatacji surowca drzewnego $\mathrm{w}$ tym regionie przekroczył $2 \mathrm{mln} \mathrm{m}^{3}$ (drugie na liście najbardziej zniszczonych nadleśnictw na terenie okupacji niemieckiej na wschodzie), mimo że ominęły to miejsce intensywne

${ }^{42}$ AAN, Komisja Rewindykacyjna, sygn. 225, Załączniki Komisji Rewindykacyjnej w Warszawie - Nadleśnictwa Lida, Jezioro, Kołpienie, Kowel, Dereczyn, Brześć, Bakszty, b.p.; Litewskie Państwowe Archiwum Historyczne (dalej: LPAH), f. 641, sygn. 699, Der Chef der Deutschen Verwaltung für Litauen, Vervaltungsbefehls, XV, nr 323, 5 IV 1916 r., k. 27; Nie wybiła godzina wybawienia z otchtani nieszczęść... Kronika dziejów Łowicza Władystawa Tarczyńskiego, oprac. M. Wojtylak, Warszawa 2015, s. 108, 125-126, 178; J. Dąbrowski, Wielka Wojna 1914-1918, Warszawa 1937, s. 406-410, 414; Der Weltkrieg. Die Siege im Osten, t. 12, Stuttgart 1917, s. 241.

${ }^{43}$ AP w Suwałkach, Leśnictwo Balińskie guberni suwalskiej, sygn. 25, Podania do leśniczego Leśnictwa Balinka, 31 III 1915 r., k. 12; 3 I 1915 r., k. 13. 
działania wojenne. Niewykluczone, że położone na północ od Białegostoku nadleśnictwo Czarna Wieś zaopatrywało w drewno twierdzę Osowiec. Rosjanie budując ten potężny kompleks forteczny, „wyczyścili” pobliski obszar ze zwartych obszarów leśnych. Wynikało to nie tylko z potrzeby dostaw ogromnej ilości surowca drzewnego przeznaczonego na wykonanie infrastruktury fortecznej, lecz miało także wpływ na obronność twierdzy. Lasy stanowiły bowiem naturalną osłonę, dająca ewentualnemu wrogowi możliwość ukrycia się lub przegrupowania. Poza tym wyrąb na obszarze przylegającym do twierdzy wydawał się dość ryzykowny. Osowiecka załoga potrzebowała jednak drewna, które należało skądś dostarczyć. Za pozyskiwaniem surowca z nadleśnictwa Czarna Wieś przemawiała chociażby odległość (ok. $60 \mathrm{~km}$ ) oraz doskonałe połaczenie kolejowe, pozostajace - tak jak cały ten obszar do września 1915 r. - w rękach Rosjan ${ }^{44}$.

Czynnikiem silnie warunkujących eksploatację była jednak dostępność materiału. Gospodarujące w lasach na ziemiach polskich niemieckie urzędy leśne pozyskiwały głównie drewno sosnowe, co wynikało naturalnie z jego obfitości. W silnie eksploatowanych kompleksach leśnych, takich jak np. Puszcza Knyszyńska, Puszcza Augustowska, Puszcza Nalibocka, lasy zaniemeńskie, dominowała właśnie sosna ${ }^{45}$. Poza tym fakt eksploatacji głównie drzewa sosnowego potwierdzaja raporty kwartalne szefa Zarządu Cywilnego GGW Wolfganga von Kriesa ${ }^{46}$.

Niemieckie instrukcje dotyczące budowy umocnień polowych wskazywały, aby w pracach fortyfikacyjnych używać „twardego drewna” ${ }^{47}$. Nie precyzowano tam jednak, jaki gatunek materiału miał być preferowany. Najwytrzymalszy surowiec pochodzi z drzew liściastych, tj. dębu, buku,

${ }^{44}$ AAN, Komisja Rewindykacyjna, sygn. 225, Załaczniki Komisji Rewindykacyjnej w Warszawie - Nadleśnictwo Czarna Wieś, b.p.; B. Perzyk, Twierdza Osowiec 1882-1915, Warszawa 2004, s. 50, 61, 73, 75, 84.

${ }^{45}$ Repozytorium Cyfrowe Instytutów Naukowych (dalej: RCIN), Mapa Lesistości Rzeczypospolitej Polskiej z okresu dwudziestolecia międzywojennego; J. Miklaszewski, Lasy i leśnictwo $w$ Polsce..., s. 465-485; L. Pączewski, dz. cyt., s. 12-13, 25-27, 30-38.

${ }^{46}$ AAN, Komitet Narodowy Polski, sygn. 596, Vierteljahrbericht des Verwaltungsschef bei dem Genera-Gouverment Warschau für die Zeit vom 1 October 1915 bis zum 31 December 1915, k. 25.

${ }^{47}$ Feld-pionierdienst aller Wassen, Berlin 1911, s. 143-149; Stellungsbau vom Juni 1916, Berlin 1916, s. 21-30. Informacje na temat budulca drzewnego wykorzystywanego do fortyfikacji polowej przekazuje m.in. wydana w 1919 r. instrukcja autorstwa Stefana Roweckiego. Powołując się m.in. na niemieckie Stellungsbau, stwierdza on, że do budowy umocnień polowych powinien być wykorzystany surowiec z drzew liściastych. Wobec ograniczonej ilości tego materiału drzewnego stosować jednak należy sosnę lub świerk; por. tenże, Umocnienie polowe, Warszawa 1919, s. 64. 
akacji, jesionu, jaworu ${ }^{48}$. Problemem staje się jednak dostępność, ponieważ lasów grądowych ${ }^{49}$ na zajętych przez Niemców obszarach Królestwa Polskiego oraz zachodnich guberni rosyjskich było za mało, aby zaspokoić potrzeby gospodarki wojennej ${ }^{50}$. Drzew liściastych potrzebował w dużej ilości przemysł chemiczny. Wytwarzano z nich oleje techniczne, garbniki, smary, alkohol etylowy, kreozot ${ }^{51}$ oraz smołę. Począwszy od 1916 r. aż do końca wojny funkcjonujące na terenie Niemiec fabryki przemysłu garbarskiego działały niemalże w całości na bazie drewna dostarczanego z obszarów okupowanych ${ }^{52}$. Materiał budowlany pochodzący z drzew liściastych był wprawdzie wykorzystywany przez oddziały niemieckich pionierów, lecz niemal wyłącznie przy budowie mostów ${ }^{53}$.

Logicznym rozwiązaniem w takiej sytuacji była eksploatacja borów iglastych. Z ogólnego obszaru leśnego na ziemiach polskich na kompleksy sosnowo-świerkowe przypadało aż $75 \%$ powierzchni, przy czym sama sosna stanowiła ok. 50\% całego drzewostanu. Podstawowa kwestia decydujacca o wykorzystaniu budulca sosnowego w pracach fortyfikacyjnych była przede wszystkim duża wytrzymałość tego drewna, wyższa niż np. świerkowego ${ }^{54}$.

48 A. Lis, P. Lis, Charakterystyka wytrzymałości drewna jako jego podstawowej właściwości mechanicznej, „Budownictwo” 2013, nr 169, z. 19, s. 81-83; W. Żenczykowski, Budownictwo ogólne, t. 1, Warszawa 1992, s. 329-330.

${ }^{49}$ Grąd to wielogatunkowy i wielowarstwowy las liściasty, zazwyczaj z przewaga grabów oraz dębów; por. A. Szweykowska, J. Szweykowski, Stownik botaniczny, Warszawa 2003 , s. 721.

${ }^{50}$ Sprawozdanie z działalności administracji lasów państwowych..., s. 63-65.

${ }^{51}$ Produkt otrzymywany ze smoły drzewnej, stosowany dawniej do produkcji środków dezynfekcyjnych (wyłącznie z drzewa bukowego), przeciwbiegunkowych, przeciwbólowych oraz impregnujących drewno (głównie podkłady kolejowe); por. G.B. Kauffman, Pittacal. The First Synthetic Dyestuff, „Journal of Chemical Education” 1977, nr 12, s. 753; D. Mączyński, Jak chroniono $w$ Polsce drewno budowlane i konstrukcyjne $w X I X i X X w$., http://www.icomos-poland.org/pl/struktura-organizacyjna/komisja-drewna/15-dominik-maczynski-jak-chroniono-w-polsce-drewno-budowlane-i-konstrukcyjnew-xix-i-xx-w.html (30 X 2017); M. Stawiak-Osińska, Ponętna, ulegta, akuratna. Ideat i wizerunek kobiety polskiej pierwszej połowy XIX w., Warszawa 2010, s. 330.

${ }^{52}$ AGAD, Szef Administracji przy Generał-Gubernatorstwie Warszawskim, sygn. 6, Vierteljahrbericht des Verwaltungsschef bei dem General-Gouverment Warschau für die zeit vom 1 April 1916 bis 31 Juni 1916, k. 8; Z. Budrewicz, Przeróbka chemiczna drzewa i jej znaczenie dla kraju, „Przemysł Chemiczny” 1922, nr 5 s. 103; A. Bader, Wald und Krieg. Wie sich in Kriegs- und Krisenzeiten die Waldbewirtschaftung veränderte. Die deutsche Forstwirtschaft im Ersten Weltkrieg, Göttingen 2011, s. 29-32, 92.

${ }^{53}$ Pionierdienst aller Wessen, Berlin 1936, s. 166; K. Kleczke, Uwagi o materiale pojazdów mostowych, „Saper i Inżynier Wojskowy” 1922, nr 7, s. 234.

${ }^{54}$ J. Miklaszewski, Ogólny rzut oka na rozwój produkcji leśnej i obrotu drzewnego Polski wspótczesnej, Warszawa 1928, s. 12; L. Krzymuski, Rolnictwo, lasy i przemyst 
Dostępność materiału drzewnego nie była jednak równomierna. Lasy w zachodnich guberniach rosyjskich (przez które przechodziła linia frontu jesienią 1915 r.), czyli na późniejszych Kresach Wschodnich II RP, miały dużo większy potencjał surowcowy niż drzewostany centralnych obszarów Królestwa Polskiego (bez Puszczy Augustowskiej) ${ }^{55}$. Kwestia ta zasadniczo decydowała o możliwości pozyskania z danego kompleksu leśnego materiału budowlanego oraz opałowego. Widać to choćby na przykładzie GGW, którego władze ubolewały, że ze względu na niewystarczajacy stopień lesistości zarządzanego przez nich terytorium zmuszone były ograniczać eksploatację ${ }^{56}$.

Jedna z najistotniejszych kwestii związanych z eksploatacja stanowił transport. Przewóz surowca drzewnego, bez względu na jego postać, należał do trudnych logistycznie zadań, szczególnie w czasie prowadzenia działań wojennych ${ }^{57}$. Władze niemieckie do transportu drewna wykorzystywały przede wszystkim kolej. Wiązało się to z jednej strony $\mathrm{z}$ dużymi kosztami przewozu, ale z drugiej zapewniało sprawne dotarcie ładunku do wyznaczonego celu. Podczas wojny czas odgrywa zasadniczą rolę. Kompleksy leśne, w pobliżu których ciagnęły się żelazne nitki szyn, były eksploatowane w zdecydowanie większym stopniu niż miejsca pozbawione trakcji kolejowej. Podobną opinię na ten temat wyrażali również inni autorzy zajmujący się tematem szacowania strat w drzewostanach powstałych w okresie I wojny światowej ${ }^{58}$.

Władze niemieckie naturalnie wykorzystywały do przewozu drewna także sieć rzeczna, lecz $\mathrm{w}$ stopniu ograniczonym. W jednym $\mathrm{z}$ wydanych przez okupacyjną administrację rozporządzeń stwierdzono nawet, że transport produktów (w tym drewna) drogą wodną ze względu na długotrwały czas podróży stanowić może jedynie odciążenie przewozów kolejowych. Nie zwracano przy tym zupełnie uwagi na oszczędności, których uzyskanie stawało się możliwe w związku z intensywniejszą

drzewny $w$ Polsce, Katowice 1928, s. 11; A. Lis, P. Lis, dz. cyt., s. 81-83; W. Żenczykowski, dz. cyt., s. 329-330.

${ }^{55}$ RCIN, Mapa Lesistości Rzeczypospolitej Polskiej z okresu dwudziestolecia międzywojennego.

${ }^{56}$ AGAD, Szef Administracji przy Generał-Gubernatorstwie Warszawskim, sygn. 12, Halbjahresbericht. Das Verwaltungschefs bei dem General-Gouverment Warschau für die Zeit vom 1 April bis 30 September 1918, k. 29; AAN, Komitet Narodowy Polski, sygn. 596, Wyciag z siódmego sprawozdania generał-gubernatora H.H. von Beselera, 13 X 1917 r., k. 123.

57 A. Szwarc, Transport drewna, Warszawa 1923, s. 5-6.

${ }^{58}$ L. Pączewski, dz. cyt., s. 37; AAN, Komisja Rewindykacyjna, sygn. 1216, Łuczycki, Rabunek niemiecki lasów polskich podczas wojny, k. 9. 
eksploatacja sieci rzecznej ${ }^{59}$. Niemniej drogi wodne wykorzystywano, powołujacc nawet specjalne jednostki wojska do obsługi transportu rzecznego. Za przykład posłużyć może nadleśnictwo Szczebra-Olszanka w dystrykcie Augustów, przez które przechodził Kanał Augustowski. Pomimo możliwości przewozów kolejowych, władze niemieckie intensywnie korzystały z pochodzacej jeszcze z XIX w. sztucznej drogi wodnej, dokonujacc nawet szeregu inwestycji budowlano-remontowych majacych przyspieszyć spław drewna ${ }^{60}$.

Osobliwym przykładem niemieckich działań eksploatacyjno-gospodarczych była Puszcza Białowieska. Okalające niewielka wieś Białowieżę lasy, będace przed wojna pod osobista opieką cara Mikołaja II (głównie ze względu na żyjące tam żubry), stanowiły poważny rezerwuar materiału drzewnego. Zarządzający od drugiej połowy 1915 r. obszarem Puszczy Białowieskiej kpt. Georg Escherich (z wykształcenia leśnik) szacował wielkość znajdującego się tam surowca na mniej więcej $35 \mathrm{mln}^{3}$. Duże możliwości eksploatacyjne wynikały jednak nie tylko z ilości surowca drzewnego, lecz także $\mathrm{z}$ faktu, że stanowił on w sporej części starodrzew. Zaskakujące wobec tego może się wydawać, że w okresie od sierpnia 1915 do listopada 1918 r. pozyskano z Puszczy Białowieskiej zaledwie ok. $1419000 \mathrm{~m}^{3}$ (wraz z Puszczą Świsłocka), przy wielkości eksploatowanego obszaru wynoszącej blisko 130 tys. ha ${ }^{61}$. Roczny wyrą wielkości ok. 470 tys. $\mathrm{m}^{3} \mathrm{z}$ pewnością nie należy do małych, jednak w porównaniu z innymi eksploatowanymi obszarami lasy białowieskie nie ucierpiały w czasie wojny aż tak dotkliwie. Dla porównania same tylko nadleśnictwo Lida (Puszcza Nalibocka), w którym wycinkę prowadzono na obszarze niespełna 20 tys. ha, straciło w czasie wojny ponad $2,6 \mathrm{mln} \mathrm{m}^{3}$ surowca drzewnego ${ }^{62}$. Dużo większe zniszczenia miały miejsce

${ }^{59}$ LPAH, f. 641, sygn. 699, Der Chef der Deutschen Verwaltung für Litauen, Vervaltungsbefehls XXV, nr 1058, 23 IX 1916 r., k. 89; W. Prus-Szczepanowki, Komunikacja leśna i przewóz drewna, „Sylwan” 1914, nr 3, s. 76-83; A. Szwarc, dz. cyt., s. 58.

${ }^{60}$ AP w Suwałkach, Tymczasowa Rada Obywatelska Okręgu Suwalskiego, sygn. 5, Protokół przejęcia administracji kanałowej z wszelkimi przyborami, 1919 r., k. 84; AP w Suwałkach, Nadleśnictwo Krasne, sygn. 43, Operat Urzędowy Nadleśnictwa Krasne, obrębu Krasne i Żyliny, 1924-1925, cz. 1, k. 8, 21; RCIN, Mapa Lesistości Rzeczypospolitej Polskiej z okresu dwudziestolecia międzywojennego; tamże, Mapa Rzeczypospolitej Polskiej i krajów ościennych, 1922 r.; tamże, Mapa Polskiej sieci kolejowej i lotniczej, $1936 \mathrm{r}$.

${ }^{61}$ LPAH, f. 641, sygn. 971, Die Bedeutung des Urwaldes von Bialowies für die deutsche Volkswirtschaft, 1917 r., k. 3; AAN, Komisja Rewindykacyjna, sygn. 225, Załączniki Komisji Rewindykacyjnej w Warszawie - Nadleśnictwa Browskie, Królewskie, Starzyńskie, Świsłocz, Hajnówka, b.p.

${ }^{62}$ AAN, Komisja Rewindykacyjna, sygn. 225, Załączniki Komisji Rewindykacyjnej w Warszawie - Nadleśnictwo Lida, b.p. 
również w mniejszej od lasów białowieskich Puszczy Augustowskiej (ok. $3 \mathrm{mln} \mathrm{m}^{3}$ przy użytkowanej wielkości $74706 \mathrm{ha}^{63}$ ) czy też Puszczy Knyszyńskiej (ok. 2,7 m³ przy użytkowanej wielkości $58501 \mathrm{ha}^{64}$ ). Wydaje się to tym bardziej dziwne, że ilość surowca oraz infrastruktura (do Puszczy Białowieskiej doprowadzona była kolej, a przepływajacca w okolicy rzeka Narew umożliwiała spław drewna) pozwalały na zdecydowanie intensywniejszą eksploatację ${ }^{65}$. Źródła, a także literatura przedmiotu nie daja przekonujacej odpowiedzi na pytanie, co hamowało wyrąb białowieskich mateczników. Pozostają w takim wypadku jedynie poszlaki, które układają się jednak w pewną całość. Pierwszą trudność mogła stanowić logistyka, głównie transport. Problem nie wynikał jednak z braku infrastruktury. Puszcza Białowieska była bodaj największym kompleksem leśnym pod niemieckim zarządem, bogatym w drzewostan liściasty. Według szacunków Eschericha ok. 30\% składu gatunkowego lasów białowieskich stanowiły dęby, buki, klony, lipy itp. Nie dziwi wobec tego, że okupanci nastawili się właśnie tutaj na eksploatację oraz przetwórstwo surowca $\mathrm{z}$ drzewa liściastego. W tym celu wybudowano ogromne zakłady w nieodległej od Białowieży miejscowości Hajnówka, które m.in. dostarczały produktów suchej destylacji drewna. Transport smukłych sosen był jednak o wiele łatwiejszy niż potężnych, białowieskich dębów. Nie mogła zmienić tego nawet okalająca Puszczę Białowieska, wybudowana przez Niemców sieć kolejki wąskotorowej. Oprócz tego wpływ na ograniczoną wielkość zniszczeń drzewostanu białowieskich lasów mógł mieć także fakt, że przez region dość szybko przetoczył się front. Puszczę Białowieską ominęły jednak nie tylko działania wojenne, lecz także zainteresowani surowcem z polskich lasów niemieccy przemysłowcy. Białowieskie lasy przez cały okres okupacji znajdowały się pod nadzorem zarządu wojskowego, który niekoniecznie cenił współpracę z władzami cywilnymi, skłonnymi nierzadko do daleko idących ustępstw wobec niemieckich przedsiębiorców ${ }^{66}$.

${ }^{63}$ Tamże, Załączniki Komisji Rewindykacyjnej w Warszawie - Nadleśnictwo Augustów, Balinka, Szczebra-Olszana, Hańcza, Krasnopol, Pomorze, b.p.

${ }_{64}$ Tamże, Załaczniki Komisji Rewindykacyjnej w Warszawie - Nadleśnictwo Knyszyn, Czarna Wieś, Sokółka, b.p.

${ }^{65}$ LPAH, f. 641, sygn. 971, Die Bedeutung des Urwaldes von Bialowies für die deutsche Volkswirtschaft, 1917 r., k. 3-4; E. Więcko, Dzieje Puszczy Białowieskiej..., s. 339; V. Wiernicka, Rosjanie w Polsce. Czas zaborów 1795-1915, Warszawa 2015, s. 238-241.

${ }^{66}$ LPAH, f. 641, sygn. 971, Die Bedeutung des Urwaldes von Bialowies für die deutsche Volkswirtschaft, 1917 r., k. 4-5; G. Escherich, Der Alte Jäger. Erinnerungen aus meinem Leben, Berlin 1936, s. 118, 152; P. Bajko, Białowieża pod rzqdami Georga Eschericha, „Czasopis” 2014, nr 9, http://czasopis.pl/bialowieza-pod-rzadami-georgaeschericha-piotr-bajko-92014/ (9 XI 2017); tenże, Białowieża pod rzqdami Georga 


\section{Zakończenie}

Przeprowadzona w powyższym tekście analiza porównawcza dotychczasowego stanu badań dotyczących strat w drzewostanie lasów skarbowych na ziemiach polskich będacych w czasie I wojny światowej pod niemiecką okupacją i dostępnego materiału źródłowego stanowiącego efekt prac Departamentu Leśnictwa wykazuje zasadniczo duże rozbieżności. Głównym tego powodem wydaje się być dobrany przez autorów materiał źródłowy. Z pewnością wiarygodniejsza analiza omawianej problematyki znalazła się w tekście autorstwa Adama Czerniakowa. Szacunki tego badacza są jednak niższe $\left(32,5 \mathrm{mln}^{3}\right.$ drewna), niż wyniki przeprowadzonej w tym artykule analizy (ok. $40 \mathrm{mln}^{3}$ drewna). Wydaje się, że Czerniaków pisząc swój artykuł w 1921 r., nie miał dostępu do całości dokumentacji z prowadzonych na potrzeby MRiDP prac, które być może w tym okresie jeszcze nie dobiegły nawet końca. Mimo to zaskakujące sa podane przez niego szacunki dotyczące wielkości zrębów (355 tys. ha wobec 77 tys. ha wskazanych przez Departament Leśnictwa) oraz nieprawdopodobny wręcz wynik obliczeń poziomu strat w drzewostanie, które w ciągu czterech lat wynieść miały 30 rocznych etatów cięć (według materiałów Departamentu Leśnictwa czteroletnie straty w drzewostanie równały się 10-11 etatom).

Zagadnienia nie naświetlają jednak wystarczająco niestety także dokumenty niemieckie. Dane w nich zawarte dotyczą wyłącznie obszaru Generalnego Gubernatorstwa Warszawskiego oraz - co bardzo istotne - odnoszą się jedynie do udokumentowanej części eksploatacji. Analizy Jabłońskiej, Kriesa oraz zespołu Grabski, Warężak i Stojanowski na temat strat $\mathrm{w}$ drzewostanie lasów GGW (zarówno prywatnych, jak i państwowych) wahały się w granicach od ok. 6 do 9,5 mln $\mathrm{m}^{3}$ surowca. Statystyki Departamentu Leśnictwa wskazywały z kolei ilość przekra-

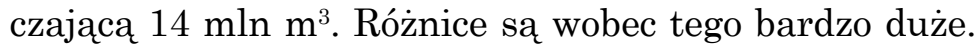

Podsumowując, należy odpowiedzieć na podstawowe pytanie dotyczące ogólnych strat w drzewostanie lasów na ziemiach polskich znajdujących się w czasie I wojny pod niemiecką okupacją. Bez wątpienia były one bardzo duże, a za główny tego powód uznać należy mająca rabunkowy charakter eksploatację gospodarcza. Podkreślić należy jednak, że straty w drzewostanie w poszczególnych regionach polskich miały różną skalę. Decydowały o tym takie kwestie jak działania wojenne, dostępność infrastruktury kolejowej oraz zasobność surowcowa danego kompleksu leśnego.

Eschericha, „Czasopis” 2014, nr 10, http://czasopis.pl/bialowieza-pod-rzadami-georgaeschericha-piotr-bajko-102014/ (9 XI 2017); I. Rivoli, Puszcza Białowieska w administracji wojskowej niemieckiej, „Przegląd Leśniczy” 1918, nr 3, s. 73-83. 
Aneks. Eksploatacja lasów na ziemiach polskich pod okupacją niemiecką w okresie I wojny światowej, z podziałem na nadleśnictwa

\begin{tabular}{|c|c|c|c|c|c|c|c|}
\hline Dystrykt & Nadleśnictwo & $\begin{array}{c}\text { Obszar } \\
\text { nadleśnictwa } \\
\text { w ha }\end{array}$ & $\begin{array}{c}\text { Obszar } \\
\text { zrębów w ha }\end{array}$ & $\begin{array}{c}\text { Obszar } \\
\text { poddany } \\
\text { zywwicowaniu } \\
\text { w ha }\end{array}$ & $\begin{array}{c}\text { Wielkość } \\
\text { eksploatacji } \\
\text { drewna użyt- } \\
\text { kowego w m } \mathbf{m}^{3}\end{array}$ & $\begin{array}{l}\text { Wielkość eks- } \\
\text { ploatacji } \\
\text { drewna opało- } \\
\text { wego w m } \text { m }^{3}\end{array}$ & $\begin{array}{l}\text { Obszar } \\
\text { nasadzeń } \\
\text { w ha }\end{array}$ \\
\hline \multirow[t]{2}{*}{ Augustów } & Balinka & 2200 & 696 & 95 & 126952 & 48260 & brak inf. \\
\hline & Augustów & 16921 & 1726 & 86 & 436143 & 185620 & 345 \\
\hline $\begin{array}{l}\text { Augustów- } \\
\text {-Suwałki }\end{array}$ & $\begin{array}{l}\text { Szczebra- } \\
\text {-Olszanka }\end{array}$ & 16761 & 1926 & 220 & 546049 & 227868 & 594 \\
\hline \multirow[t]{2}{*}{ Będzin } & Będzin & 8995 & 1493 & 164 & 248311 & 33031 & 100 \\
\hline & Dąbrowa & 5352 & 448 & brak inf. & 75133 & 8069 & brak inf. \\
\hline Biała & Janów-Biała & 12000 & 2149 & brak inf. & 550770 & 231355 & brak inf. \\
\hline \multirow[t]{5}{*}{ Białowieża } & Browskie & 31431 & 424 & 686 & 273949 & 222574 & brak inf. \\
\hline & Królewskie & 29809 & 249 & 203 & 106655 & 120912 & brak inf. \\
\hline & Starzyńskie & 22254 & 979 & 40 & 111927 & 89498 & brak inf. \\
\hline & Świsłocz & 23793 & 44 & 254 & 15978 & 1500 & brak inf. \\
\hline & Hajnówka & 21692 & 879 & brak inf. & 283962 & 222574 & brak inf. \\
\hline Białystok & Knyszyn & 12001 & 805 & 85 & 247068 & 135231 & 1596 \\
\hline \multirow[t]{2}{*}{ Bielsk } & Hołdy & 8864 & 1031 & 513 & 228236 & 83814 & 423 \\
\hline & Mielniki & 11000 & 903 & 406 & 361299 & 109684 & 1086 \\
\hline \multirow[t]{2}{*}{ Brześć } & Brześśc & 8864 & 1031 & 513 & 228236 & 83814 & 423 \\
\hline & Małosychie & 11000 & 903 & 406 & 361299 & 109684 & 1086 \\
\hline \multirow[t]{2}{*}{ Brzeziny } & Brzeziny & 5660 & 375 & 219 & 161012 & 63257 & 1066 \\
\hline & Widy & 11654 & 350 & brak inf. & 127680 & 15660 & brak inf. \\
\hline
\end{tabular}




\begin{tabular}{|c|c|c|c|c|c|c|c|}
\hline \multirow[t]{3}{*}{ Częstochowa } & Zagórze & 11936 & 534 & 149 & 129089 & 30069 & 1701 \\
\hline & Częstochowa & 12379 & 950 & 353 & 252932 & 55918 & 228 \\
\hline & Olsztyn & 7695 & 779 & brak inf. & 168556 & 32459 & 1922 \\
\hline Dzisna & Dzisna & 12962 & 488 & brak inf. & 74829 & 47640 & brak inf. \\
\hline Garwolin & Garwolin & 2000 & 197 & brak inf. & 55308 & 49343 & 1602 \\
\hline \multirow{3}{*}{ Grodno } & Grodno & 17633 & 1247 & 143 & 396653 & 150876 & brak inf. \\
\hline & Jezioro & 15739 & 0 & 515 & 379056 & 777787 & 15739 \\
\hline & Druskienniki & 23792 & 496 & brak inf. & 57894 & 21385 & 2160 \\
\hline Kamień & Prypeć & 12710 & 125 & 270 & 21000 & brak inf. & brak inf. \\
\hline Kobryń & Kobryń & 23893 & 121 & brak inf. & 318383 & 94170 & 1548 \\
\hline \multirow[t]{2}{*}{ Kolno } & Kolno & 8460 & 556 & brak inf. & 252688 & 39021 & 1983 \\
\hline & Lipniki & 8186 & 748 & brak inf. & 259798 & 30537 & brak inf. \\
\hline Kolno-Łomża & Nowogród & 10125 & 1222 & 157 & 254958 & 106664 & 1580 \\
\hline $\begin{array}{l}\text { Kolno-Szczu- } \\
\text { czyn }\end{array}$ & Grajewo & 12802 & 657 & 110 & 368742 & 87114 & 1880 \\
\hline Koło & Koło & 5828 & 359 & 185 & 77464 & 22345 & 492 \\
\hline $\begin{array}{l}\text { Kossów- } \\
\text {-Prużany }\end{array}$ & Bereza Kartuska & 14700 & 269 & brak inf. & 56462 & 22782 & brak inf. \\
\hline $\begin{array}{l}\text { Kossów- } \\
\text {-Słonim }\end{array}$ & Różany & 21561 & 54 & brak inf. & 49718 & 20177 & 137 \\
\hline \multirow[t]{4}{*}{ Kowel } & Kowel & 18000 & 2158 & brak inf. & 770104 & 306140 & 1218 \\
\hline & Krymno & 15301 & 253 & 300 & 37950 & 17130 & 674 \\
\hline & Trojanowek & 16109 & 1500 & brak inf. & 435000 & 165000 & 7000 \\
\hline & Zabłocie & 19817 & 0 & 50 & 23550 & 6760 & 3110 \\
\hline
\end{tabular}




\begin{tabular}{|c|c|c|c|c|c|c|c|}
\hline Dystrykt & Nadleśnictwo & $\begin{array}{c}\text { Obszar } \\
\text { nadleśnictwa } \\
\text { w ha }\end{array}$ & $\begin{array}{c}\text { Obszar } \\
\text { zrębów w ha }\end{array}$ & $\begin{array}{c}\text { Obszar } \\
\text { poddany } \\
\text { żywicowaniu } \\
\text { w ha }\end{array}$ & $\begin{array}{c}\text { Wielkość } \\
\text { eksploatacji } \\
\text { drewna użyt- } \\
\text { kowego } \mathbf{w} \mathbf{m}^{3}\end{array}$ & $\begin{array}{l}\text { Wielkość eks- } \\
\text { ploatacji } \\
\text { drewna opało- } \\
\text { wego } \mathrm{w} \mathrm{m}^{3}\end{array}$ & $\begin{array}{c}\text { Obszar } \\
\text { nasadzeń } \\
\text { w ha }\end{array}$ \\
\hline \multirow[t]{2}{*}{ Lida } & Lida & 18944 & 3497 & brak inf. & 1950198 & 729816 & brak inf. \\
\hline & Koniawy & 35549 & 667 & 1010 & 205464 & 266668 & brak inf. \\
\hline Lipno & Lipno & 5764 & 1242 & 83 & 225590 & 49998 & brak inf. \\
\hline \multirow[t]{2}{*}{ Lubomla } & Szack & 13948 & 406 & 267 & 78325 & 17652 & 150 \\
\hline & Lubomla & 18877 & 50 & 100 & 32000 & 15000 & 280 \\
\hline Lask & Czarnocin-Łask & 7711 & 534 & 79 & 75040 & 23356 & 1350 \\
\hline Lomża & Zambrów & 8390 & 1145 & 25 & 164799 & 294319 & brak inf. \\
\hline Luków & Łuków & 14051 & 496 & 119 & 80810 & 41210 & 468 \\
\hline Luniniec & Łuniniec & 11940 & 0 & brak inf. & 198 & 98 & 2 \\
\hline Ostrołęka & Ostrołęka & 12060 & 1472 & 165 & 393640 & 203526 & 3271 \\
\hline \multirow[t]{4}{*}{ Ostrów } & Myszyniec & 9159 & 743 & 95 & 285165 & 194497 & 1332 \\
\hline & Wiśniewo & 9014 & 613 & 118 & 230595 & 67915 & 1 \\
\hline & Jagiel & 10390 & 1861 & brak inf. & 334579 & 139455 & 1424 \\
\hline & Ostrów & 11121 & 1550 & brak inf. & 566665 & 182897 & 4948 \\
\hline Pińsk & Pińsk & 39731 & 553 & brak inf. & 240043 & 50197 & 622 \\
\hline \multirow[t]{3}{*}{ Przasnysz } & Jednorożec & 8324 & 770 & 125 & 527633 & 135298 & 2806 \\
\hline & Chorzele & 7248 & 662 & 13 & 94065 & 34725 & brak inf. \\
\hline & Rzaniec & 7135 & 1938 & 81 & 124685 & 32212 & brak inf. \\
\hline Prużany & Szereszemy & 10292 & 170 & brak inf. & 29750 & 12750 & brak inf. \\
\hline \multirow[t]{2}{*}{ Pułtusk } & Pułtusk & 7976 & 507 & 1 & 283045 & 120496 & 1636 \\
\hline & Lemany & 10073 & 1120 & 124 & 195544 & 59528 & brak inf. \\
\hline
\end{tabular}




\begin{tabular}{|c|c|c|c|c|c|c|c|}
\hline Rawa & Spała & 10200 & 213 & brak inf. & 387562 & 50232 & 1474 \\
\hline Rawa-Brzeziny & Regny & 5718 & 892 & 207 & 219494 & 100428 & 890 \\
\hline \multirow[t]{4}{*}{ Sarny } & Styr & 11497 & 480 & brak inf. & 64000 & 32000 & brak inf. \\
\hline & Czartorysk & 19735 & 0 & 0 & 0 & 0 & 0 \\
\hline & Snowiedowice & 9150 & brak inf. & brak inf. & 1500 & brak & 8 \\
\hline & Sarny & 26587 & 0 & 0 & 0 & 0 & brak inf. \\
\hline \multirow{2}{*}{ Sejny } & Krasnopol & 13534 & 1191 & 80 & 587774 & 163458 & 1298 \\
\hline & Pomorze & 13766 & 264 & 588 & 227809 & 14046 & 10818 \\
\hline Sieradz & Sieradz & 10027 & 1553 & 110 & 84635 & 100836 & 10027 \\
\hline Skierniewice & Skierniewice & 9001 & 1511 & brak inf. & 200006 & 143051 & 333 \\
\hline Słonim & Słonim & 13491 & 668 & brak inf. & 161748 & 26038 & brak inf. \\
\hline $\begin{array}{l}\text { Sochaczew- } \\
\text {-Błonie }\end{array}$ & Kampinos & 11654 & 814 & 255 & 155927 & 114958 & 3179 \\
\hline \multirow[t]{2}{*}{ Sokółka } & Sokółka & 19000 & 2158 & 294 & 157883 & 17472 & 175 \\
\hline & Czarna Wieś & 27500 & 1741 & 991 & 1597931 & 529307 & 4736 \\
\hline \multirow[t]{2}{*}{ Suwałki } & Suwałki & 7725 & 1264 & 251 & 555092 & 68868 & 1108 \\
\hline & Puńsk & 4302 & 148 & 151 & 161996 & 45864 & 2069 \\
\hline Suwałki-Sejny & Podmiejskie & 7352 & 109 & 297 & 182966 & 77567 & 3788 \\
\hline Szczuczyn & Rajgród & 7000 & 956 & 16 & 394571 & 92858 & 1719 \\
\hline Turek-Łęczyca & Uniejów & 8899 & 686 & 114 & 119428 & 110509 & 2208 \\
\hline Warszawa & Pomiechówek & 4084 & 625 & 25 & 516200 & 54442 & 1255 \\
\hline $\begin{array}{l}\text { Warszawa- } \\
\text {-Radzymin }\end{array}$ & $\begin{array}{l}\text { Warszawa- } \\
\text {-Wschód }\end{array}$ & 4700 & 379 & brak inf. & 154715 & 19200 & 334 \\
\hline
\end{tabular}




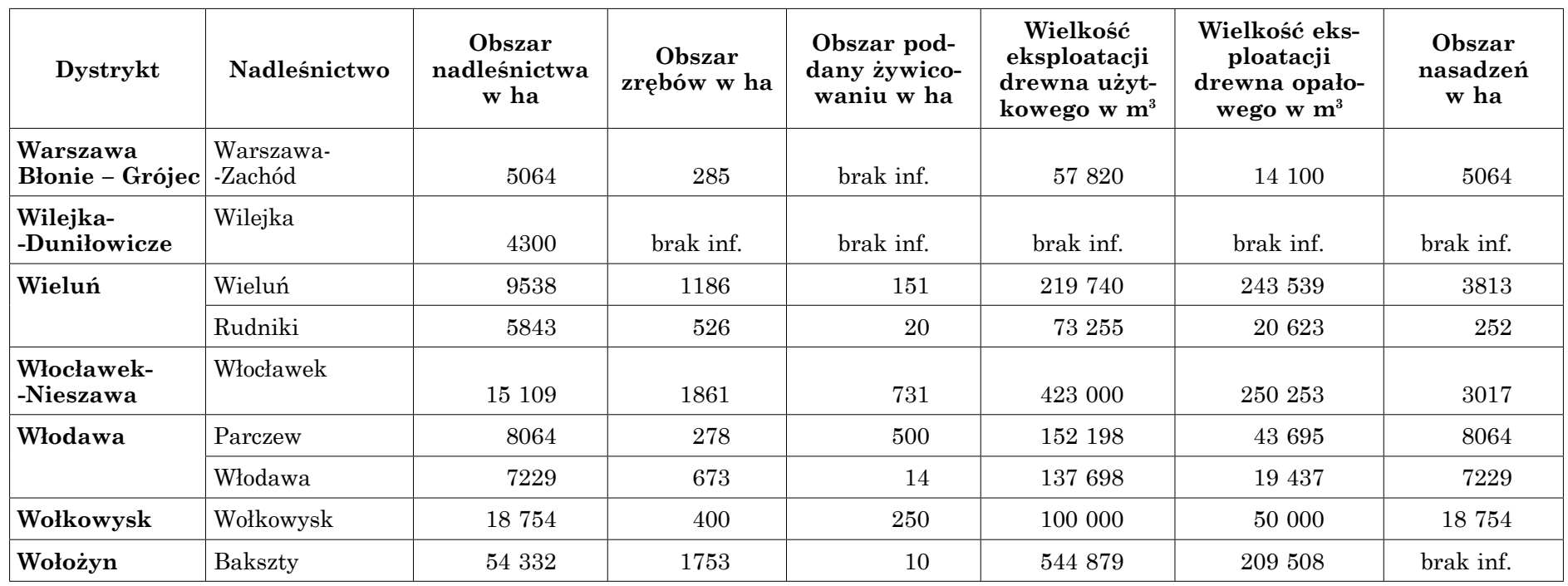

Źródło: AAN, Komisja Rewindykacyjna, sygn. 311, Załączniki Komisji Rewindykacyjnej w Warszawie. 


\section{Bibliografia}

Bielański K., O las polski, „Las Polski” 1921, nr 1, s. 9-25.

Broda J., Dzieje najnowsze leśnictwa w Polsce 1918-2006, t. 1, Warszawa 2007. Fromer R., Okres pierwszej wojny światowej, w: Dzieje lasów, leśnictwa $i$ drzewnictwa $w$ Polsce, red. J. Broda, A. Zabko-Potapowicz, Warszawa 1965, s. 304-308.

Grabski W., Warężak J., Stojanowski J., Rolnictwo Polski 1914-1920, w: Polska w czasie wielkiej wojny (1914-1918). Historia spoteczna i ekonomiczna, t. 3: Historia ekonomiczna, red. M. Handelsman, H. Gliwic, W. Grabski, K. Konarski, K.W. Kumaniecki, S. Kutrzeba, J. Stachiewicz, Oświęcim 2015, s. 257-339.

Gierowska-Kałłaur J., Zarzad Cywilny Ziem Wschodnich, Warszawa 2003.

Kozyra W., Polityka administracyjna wtadz polskich na Ziemiach Wschodnich Rzeczypospolitej Polskiej w latach 1918-1926, „Annales Universitatis Mariae Curie Skłodowska. Sectio F’ 2005, nr 59, s. 419-440.

Latałowa M., Zimny M., Jędrzejewska B., Samojlik T., Ecological History of Białowieża Forest - Europe's Last Primeval Woodland, w: The Ecological History of European Woodland an Interaction of Environmental and Cultural Forces, red. K. Kirby, C. Watkins, Oxford 2015, s. 243-264.

Miklaszewski J., Lasy i leśnictwo w Polsce, t. 1, Warszawa 1928.

Więcko E., Dzieje Puszczy Białowieskiej od rozbiorów do roku 1918, KHKM, t. $11,1963, \mathrm{nr} 2$, s. 298-352.

Łukasz Faszcza

Losses in the stand of treasury forests incurred in warfare and exploitation during World War I

(Summary)

The scale of destruction in the Treasury forests of the Kingdom of Poland and the western governorates of the Russian state (Vilna, Minsk, Volhynia, Grodno) which came under German occupation during World War II was very large. The estimates made by the Department of Forestry after the end of the conflict showed that the forest stand had lost ca. $40 \mathrm{mln} \mathrm{m}^{3}$ of raw material. This number was equivalent to the volume of wood produced in 10-11 annual allowable cuts. Undoubtedly, the losses resulted primarily from the long months of trench warfare which brought large-scale devastation of forested areas, inflicted by the soldiers fighting on both sides of the conflict and by the civilian population. A secondary cause of the destruction was the economic exploitation of forests by the German occupier. The scale of cuts was mostly dictated by the availability of transportation infrastructure, primarily railways. The exploitation was additionally curbed by the limited availability of the resource, the level of development in a given forested area, 
and the type of produced wood. A good example of these phenomena was the case of the Białowieża Forest. Cutting the large oaks growing in the forest was an extremely labor-intensive endeavor, and the cutting conditions were hardly improved by the large-scale expansion of the network of narrow-gauge railways.

Lukasz Faszcza - doktorant na Wydziale Historycznym Uniwersytetu Warszawskiego, pracownik Muzeum Ziemi Augustowskiej w Augustowie. Swoje zainteresowania badawcze koncentruje na historii Suwalszczyzny oraz problematyce gospodarczej w XIX w. i podczas I wojny światowej.

Lukasz Faszcza - PhD candidate at the Faculty of History, University of Warsaw, employee of the Museum of Augustów Land in Augustów. His academic interests focus on issues related to the history of the Suwalszczyzna region and economic issues in the nineteenth century and during World War I.

E-mail: lukaszfaszcza@wp.pl. 